\title{
is Research Square \\ Short Reports Low Prevalence of Toxoplasma Gondii DNA in the Fresh Milk of Cattle in China
}

\section{Yong-Liang Wang}

Jilin Agricultural University

QingFeng Meng ( $\nabla$ mqfboy@163.com )

Jilin Agricultural University https://orcid.org/0000-0002-6232-4153

Research article

Keywords: Toxoplasma gondii, Milk, Cattle, China

Posted Date: September 8th, 2020

DOI: https://doi.org/10.21203/rs.3.rs-62998/v1

License: (9) This work is licensed under a Creative Commons Attribution 4.0 International License.

Read Full License 


\section{Abstract}

Background: It is generally recognized that there is a risk for humans to acquire toxoplasmosis through consumption of raw milk from infected animals. Although several studies have been conducted to detect the seroprevalence of $T$. gondii in cattle in China, no study has been conducted to detect T. gondii DNA in milk of cattle in China. Thus, the present study was firstly conducted to explore the prevalence of $T$. gondii DNA in fresh milk of cattle in China.

Results: A total of 2092 blood samples and fresh bovine milk were collected from six provinces between January 2018 and June 2019, respectively, and examined by ELISA and semi-nested PCR, respectively. In total, $123 / 2092(5.88 \%)$ of the blood samples and $22 / 2092(1.05 \%)$ of the milk samples were positive for T. gondii, respectively. Fifteen of these 22 positive milk samples (68.18\%) were animals who also recorded serologically positive. Moreover, cattle and milk from family farming have significantly higher $T$. gondii prevalence than those from commercial farm.

Conclusions: To our knowledge, this is the first report of T. gondii DNA was found in the fresh milk of cattle in China, suggesting that the consumption of raw milk from seropositive cattle could be a potential source of human infection.

\section{Background}

Toxoplasmosis is a global zoonotic parasitic diseases, caused by Toxoplasma gondii, an important opportunistic protozoa, which can cause great financial losses, especially for the animal production industries, and is of great importance for public health [1-3]. All kinds of hosts may be infected through ingestion of $T$. gondii oocysts or cysts containing bradyzoites, via ingestion of tachyzoites in nonpasteurized milk products or through the transplacental transmission [4].

Tachyzoites of $T$. gondii have been detected and isolated from the milk of numerous species and milk has been considered as a significant source of $T$. gondii infection in humans [4-8]. Experimental studies on animal models have indicated that tachyzoites existed in the milk of infected animals and could transmit to their offspring [5]. Moreover, some studies has shown that humans can be infected with $T$. gondii through consuming non-pasteurized goat milk $[9,10]$. Several studies have been conducted to detect the seroprevalence of $T$. gondii in cattle in China [11-15], but, until now, no study has been conducted to detect $T$. gondii DNA in milk of cattle in China. Thus, in view of this information is scarce, the present study was firstly carried out to explore the prevalence of $T$. gondii DNA in fresh milk of cattle in China.

\section{Methods}

\section{Sample collection}


A total of 2092 blood samples and fresh bovine milk were collected from six provinces (Heilongjiang, Jilin, Shandong, Hebei, Shanxi, Inner Mongolia and Xinjiang) (Figure 1) between January 2018 and June 2019, respectively. Cattle were handled with good ethical animal practices required by the Animal Ethics Procedures and Guidelines of the People's Republic of China. Permission has been obtained from the owners of cattle to collect the serum samples. In the present study, clinically healthy animals were sampled and sick animals were excluded. For blood sampling, $10 \mathrm{ml}$ blood sampling of each cattle were collected from the tail vessel by sterile tubes sans/without anticoagulant. The blood samples were transferred to the lab by the ice box and stored at $4^{\circ} \mathrm{C}$ for 2 hour and then centrifuged at $1500 \times g$ for 10 min. After this, the serum was obtained and stored at $-20^{\circ} \mathrm{C}$ for serology. For the milk sampling, teats was firstly been cleaned and disinfected with iodine solution ( $0.5 \%)$, then milk was manually collected. The first few squirts were excluded. Then, approximately $5 \mathrm{ml}$ of milk was collected in sterile glass tubes and frozen for molecular examination.

\section{Serology}

IgG antibodies against $T$. gondii was detected by a commercially available ELISA kit (ID Screen ${ }^{\circledR}$ Toxoplasmosis Indirect, Montpellier, France) following the instructions of the manufacturer.

\section{Molecular examination to detect the T. gondii DNA}

The commercial QIAamp DNA mini kit (Qiagen, GmbH, Hilden, Germany) was employed to extract the genomic DNA from milk samples following the instructions of the manufacturer. After extraction, the DNA samples were stored at $-20 \circ \mathrm{C}$ until used.

To detect the presence of $T$. gondii DNA in fresh milk of cattle, a semi-nested PCR targeting the $T$. gondii B1 gene was employed as previously described elsewhere [16]. Positive controls of DNA from parasiteinfected mice and negative control from non-infected mice (PBS) were included throughout the whole examination.

\section{Results}

In the serum samples, 123/2092 (5.88\%) of the animals were positive for T. gondii (Table 1). Among the age category, the highest seroprevalence was detected in cattle of 2-3 year old category (6.26\%), followed by $>5$ year old category $(5.95 \%)$ and $4-5$ year old category $(5.63 \%)$. In view of the geographical origin, $T$. gondii seroprevalence varied in cattle from different regions, ranging from $4.14 \%$ in Shandong province to $6.59 \%$ in Inner Mongolia Autonomous Region (Table 1). Moreover, cattle from family farming $(9.48 \%)$ have a significantly higher $T$. gondii seroprevalence than those from commercial farm $(5.26 \%)(P<0.01)$. The samples collected in 2018 (5.78\%) have a similar seroprevalence with those collected in 2019 (5.97\%).

In the milk samples, the T. gondii DNA was detected in 22/2092 (1.05\%) of the milk samples. Fifteen of these 22 positive milk samples $(68.18 \%)$ were animals who also recorded positive samples in the 
serology. The T. gondii DNA prevalence in $>5$ year old category $(0.05 \%)$ was lower than that in other categories. Moreover, milk from family farming (3.27\%) have a significantly higher $T$. gondii prevalence than those from commercial farm $(0.07 \%)(P<0.01)$.

\section{Discussion}

It is believed that almost a third of human worldwide has been infected with $T$. gondii $[2,17]$. Regions with hot, humid climates and lower altitudes are considered to contribute to the infection of T. gondii [1]. Although $T$. gondii can infect all kinds of warm-blooded animal, cattle with a more effective immune response to $T$. gondii infection are considered as poor hosts for $T$. gondii compared with other animals, such as sheep or goat [18-20]. However, cattle tissues and unpasteurized milk has been proved to contain virulent T. gondii [20], suggesting that human may get infection through consuming the meat and milk.

In the present study, T. gondii DNA was detected in 22/2092 (1.05\%) fresh milk samples of cattle, suggesting that natural infection has been occurred in these farms. This information is very important because some families in those farms consume milk very day, indicating that they are at a risk of exposure for T. gondii. Moreover, cattle and milk from family farming have significantly higher $T$. gondii prevalence than those from commercial farm, suggesting that cattle and milk from family farming have more chance to connect with $T$. gondii, thus, more preventive measure should be recommended in family farming. More disease awareness efforts should be carried out among individual farmers.

It is generally believed that tachyzoites, the stage most likely present in milk, could be immediately destroyed by the gastric juice when we consumed the unpasteurized milk or its products [21]. To our disappointment, ingested tachyzoites have been verified to can cause infection [22]. T. gondii exists in unpasteurized or unseemly processed milk or fresh cheese, can be a significant risk for the people lived in the rural regions because they are their major food source [23].

Positive results of the PCR showed that T. gondii DNA exist in the milk, but this result is still not enough to verdict the possible transmission of toxoplasmosis by directly ingesting the fresh milk because no living parasites have been isolated from the fresh milk in the present study. However, the present results have already indicated that chronic infection of $T$. gondii has been occurring in these positive cattle, especially for those of $T$. gondii DNA detection in milk who also recorded positive samples in the serology, providing useful information for future studies.

\section{Conclusion}

Although low prevalence of $T$. gondii DNA has been detected in the fresh milk of cattle by molecular analysis, it is still possible that toxoplasmosis transmission may occur in some rural regions because milk is used for subsistence without pasteurization or boiling prior to consumption. However, more studies should be carried out to explore the possible transmission of toxoplasmosis by directly ingesting the fresh milk or its products. 


\section{Abbreviations}

ELISA: Enzyme-linked Immunosorbent Assay; PCR: Polymerase Chain Reaction

\section{Declarations}

\section{Acknowledgements}

The authors would like to thank the owners of cattle for their involvement in the study. We are grateful to the veterinary staff for their help with the collection of blood samples.

\section{Authors' contributions}

QFM conceived and designed the study and critically revised the manuscript. YLW collected the samples, performed the experiments, analysed the data and drafted the manuscript. All authors read and approved the final manuscript.

\section{Funding}

Project support was provided by the Science and Technology Development Plan of Jilin Province (Grant No. 20180520034JH). The founder had no role in the study design, sample collection, detection, sequencing, analysis and interpretation, or the manuscript preparation.

\section{Availability of data and materials}

The datasets used and analyzed during the study are available from the corresponding author on reasonable request.

\section{Ethics approval and consent to participate}

The present study was approved by the Animal Ethics Committee of Jilin Agricultural University (Approval No. JLAU 2018-006). The samples were collected and handled in accordance with the good animal practices required by the Animal Ethics Procedures and Guidelines of the People's Republic of China.

\section{Consent for publication}

Not applicable.

\section{Competing interests}

The authors declare that they have no competing interests.

\section{Author details}


${ }^{1}$ College of Animal Science and Technology, Jilin Agricultural University, Changchun, Jilin Province, The People's Republic of China. ${ }^{2}$ Technology center of Changchun Customs, Jilin Province, PR China.

\section{References}

1. Dubey JP. Toxoplasmosis of animals and humans. 2nd ed. Boca Raton: CRC Press. 2010.

2. Montoya JG, Liesenfeld O. Toxoplasmosis. Lancet. 2004;363(9425),1965-1976.

3. Cong W, Zhang NZ, Hu RS, Zou FC, Zou Y, Zhong WY, Wu JJ, Fallaize CJ, Zhu XQ, Elsheikha HM. Prevalence, risk factors and genotype distribution of Toxoplasma gondii DNA in soil in China. Ecotoxicol Environ Saf. 2020;189.

4. Bezerra MJ, Kim PC, Moraes EP, Sa SG, Albuquerque PP, Silva JG, Alves BH, Mota RA. Detection of Toxoplasma gondii in the milk of naturally infected goats in the Northeast of Brazil. Transbound Emerg Dis. 2015;62(4),421-424.

5. Costa VM, Langoni H. Detection of Toxoplasma gondii in the milk of experimentally infected Wistar female rats. J Venom Anim Toxins Incl Trop Dis. 201;16:368-74.

6. Powell CC, Brewer M, Lappin MR. Detection of Toxoplasma gondii in the milk of experimentally infected lactating cats. Vet Parasitol. 2001;102(1-2),29-33.

7. Ranucci D, Battisti E, Veronesi F, Diaferia M, Morganti G, Branciari R, Ferroglio E, Valiani A, Chiesa F. Absence of Viable Toxoplasma gondii in Artisanal Raw-Milk Ewe Cheese Derived from Naturally Infected Animals. Microorganisms.2020;8(1).

8. Dubey JP, Verma SK, Ferreira LR, Oliveira S, Cassinelli AB, Ying Y, Kwok OC, Tuo W, Chiesa OA, Jones JL. Detection and survival of Toxoplasma gondii in milk and cheese from experimentally infected goats. J Food Prot. 2014;77(10),1747-1753.

9. Skinner LJ, Timperley AC, Wightman D, Chatterton JM, Ho-Yen DO. Simultaneous diagnosis of toxoplasmosis in goats and goatowner's family. Scand J Infect Dis. 1990;22(3),359-361.

10. Pinto-Ferreira F, Caldart ET, Pasquali A, Mitsuka-Bregano R, Freire RL, Navarro IT. Patterns of Transmission and Sources of Infection in Outbreaks of Human Toxoplasmosis. Emerg Infect Dis. 2019;25(12),2177-2182.

11. Dong H, Lu YY, Su RJ, Wang YH, Wang MY, Jiang YB, Yang YR. Low prevalence of antibodies against Toxoplasma gondii in dairy cattle from China's central region. BMC Vet Res. 2018;14(1), 315.

12. Luo H, Li K, Zhang H, Gan P, Shahzad M, Wu X, Lan Y, Wang J. Seroprevalence of Toxoplasma gondii infection in zoo and domestic animals in Jiangxi Province, China. Parasite. 2017;24,7.

13. Sun WW, Meng QF, Cong W, Shan XF, Wang CF, Qian AD. Herd-level prevalence and associated risk factors for Toxoplasma gondii, Neospora caninum, Chlamydia abortus and bovine viral diarrhoea virus in commercial dairy and beef cattle in eastern, northern and northeastern China. Parasitol Res. 2015;114(11),4211-4218.

14. Qiu JH, Wang CR, Zhang X, Sheng ZH, Chang QC, Zhao Q, Wu SM, Zou FC, Zhu XQ. Seroprevalence of Toxoplasma gondii in beef cattle and dairy cattle in northeast China. Foodborne Pathog Dis. 
2012;9(7),579-582.

15. Zhou DH, Zhao FR, Lu P, Xia HY, Xu MJ, Yuan LG, Yan C, Huang SY, Li SJ, Zhu XQ. Seroprevalence of Toxoplasma gondii infection in dairy cattle in southern China. Parasit Vectors. 2012;5,48.

16. Cong W, Liu GH, Meng QF, Dong W, Qin SY, Zhang FK, Zhang XY, Wang XY, Qian AD, Zhu XQ. Toxoplasma gondii infection in cancer patients: prevalence, risk factors, genotypes and association with clinical diagnosis. Cancer Lett. 2015;359(2),307-313.

17. Weiss LM, Dubey JP. Toxoplasmosis: A history of clinical observations. Int J Parasitol. 2009;39(8),895-901.

18. Esteban-Redondo I, Innes EA. Toxoplasma gondii infection in sheep and cattle. Comp Immunol Microbiol Infect Dis. 1997;20(2),191-196.

19. Dubey JP. A review of toxoplasmosis in cattle. Vet Parasitol. 1986;22(3-4),177-202.

20. Munday BL, Corbould A. Serological responses of sheep and cattle exposed to natural Toxoplasma infection. Aust J Exp Biol Med Sci. 1979.57(2),141-145.

21. Dubey JP. Re-examination of resistance of Toxoplasma gondii tachyzoites and bradyzoites to pepsin and trypsin digestion. Parasitology. 1998;116,43-50.

22. Hiramoto RM, Mayrbaurl-Borges M, Galisteo AJ, Meireles LR, Macre MS, Andrade HJ. Infectivity of cysts of the ME-49 Toxoplasma gondii strain in bovine milk and homemade cheese. Rev Saude Publica. 2001;35(2),113-118.

23. Cook AJ, Gilbert RE, Buffolano W, Zufferey J, Petersen E, Jenum PA, Foulon W, Semprini AE, Dunn DT. Sources of toxoplasma infection in pregnant women: European multicentre case-control study. European Research Network on Congenital Toxoplasmosis. BMJ. 2000;321(7254),142-147.

\section{Tables}

Table 1. Seroprevalence of T. gondii infection in blood samples of cattle in China 


\begin{tabular}{|c|c|c|c|c|c|}
\hline Variable & Category & No. tested & No. positive & Prevalence (\%) & $P$-value \\
\hline \multirow[t]{3}{*}{ Age } & 2-3 year & 607 & 38 & 6.26 & 0.870 \\
\hline & 4-5 year & 1065 & 60 & 5.63 & \\
\hline & $>5$ year & 420 & 25 & 5.95 & \\
\hline \multirow[t]{7}{*}{ Region } & Heilongjiang & 263 & 16 & 6.08 & 0.931 \\
\hline & Jilin & 344 & 19 & 5.52 & \\
\hline & Inner Mongolia & 440 & 29 & 6.59 & \\
\hline & Shandong & 241 & 10 & 4.14 & \\
\hline & Xinjiang & 279 & 17 & 6.09 & \\
\hline & Shanxi & 281 & 17 & 6.05 & \\
\hline & Hebei & 244 & 15 & 6.15 & \\
\hline \multirow[t]{2}{*}{ Feeding model } & Commercial farm & 1786 & 94 & 5.26 & 0.004 \\
\hline & Family farming & 306 & 29 & 9.48 & \\
\hline \multirow[t]{2}{*}{ Sampling time } & 2018 year & 969 & 56 & 5.78 & 0.856 \\
\hline & 2019 year & 1123 & 67 & 5.97 & \\
\hline Total & & 2092 & 123 & 5.88 & \\
\hline
\end{tabular}

Table 2. Prevalence of T. gondii DNA in fresh milk of cattle in China. Prevalence of T. gondii DNA in fresh milk of cattle in China 


\begin{tabular}{|c|c|c|c|c|c|}
\hline Variable & Category & No. tested & No. positive & Prevalence (\%) & $P$-value \\
\hline \multirow[t]{3}{*}{ Age } & 2-3 year & 607 & 9 & 1.48 & 0.298 \\
\hline & 4-5 year & 1065 & 11 & 1.03 & \\
\hline & $>5$ year & 420 & 2 & 0.05 & \\
\hline \multirow[t]{7}{*}{ Region } & Heilongjiang & 263 & 3 & 1.14 & 0.992 \\
\hline & Jilin & 344 & 3 & 0.09 & \\
\hline & Inner Mongolia & 440 & 4 & 0.09 & \\
\hline & Shandong & 241 & 2 & 0.08 & \\
\hline & Xinjiang & 279 & 4 & 1.43 & \\
\hline & Shanxi & 281 & 3 & 1.07 & \\
\hline & Hebei & 244 & 3 & 1.22 & \\
\hline \multirow[t]{2}{*}{ Feeding model } & Commercial farm & 1786 & 12 & 0.07 & $<0.001$ \\
\hline & Family farming & 306 & 10 & 3.27 & \\
\hline \multirow[t]{2}{*}{ Sampling time } & 2018 year & 969 & 10 & 1.03 & 0.941 \\
\hline & 2019 year & 1123 & 12 & 1.07 & \\
\hline Total & & 2092 & 22 & 1.05 & \\
\hline
\end{tabular}

Figures 


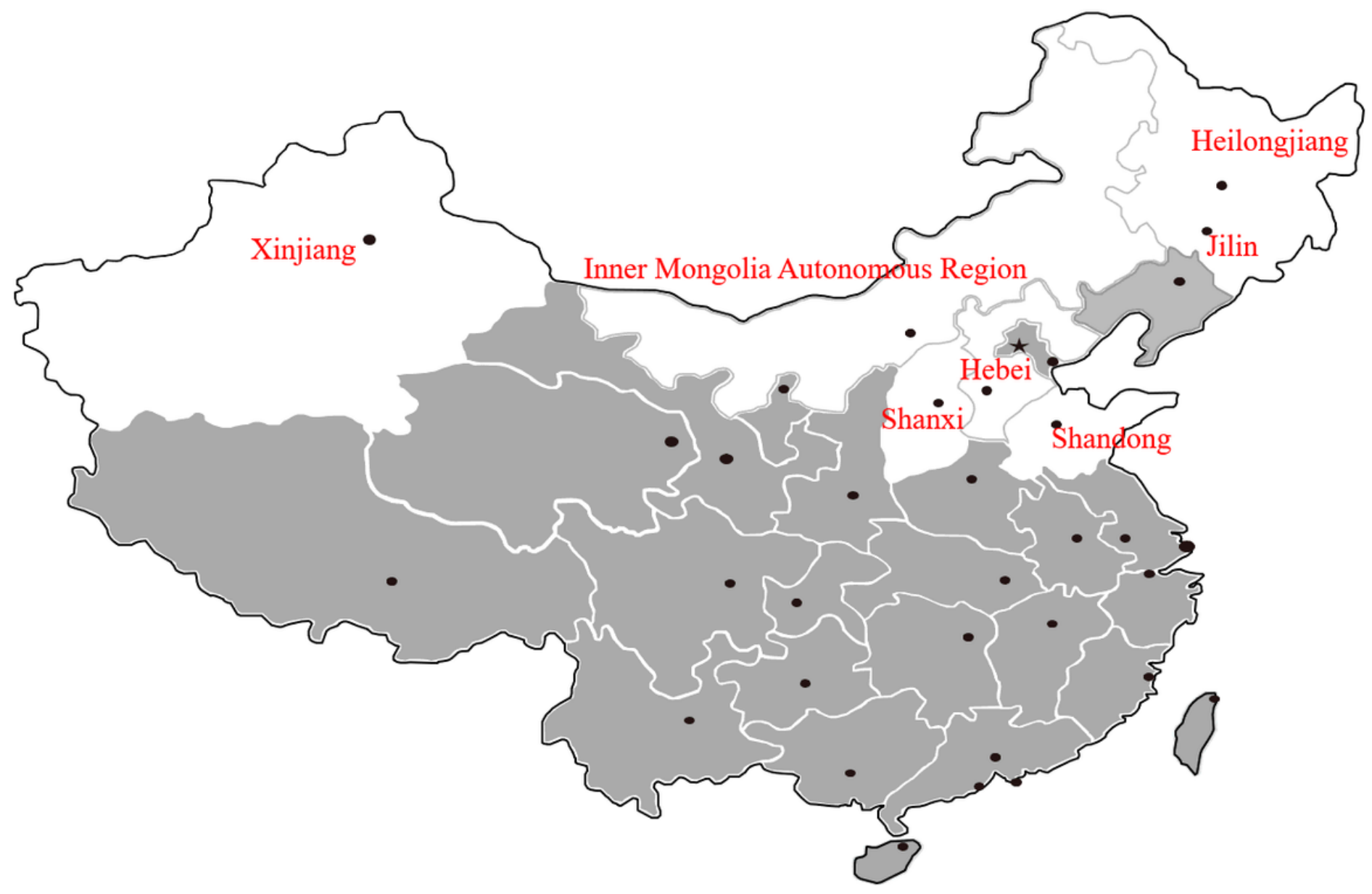

Figure 1

The map of China, showing the locations of samples collected from cattle in the present study. Note: The designations employed and the presentation of the material on this map do not imply the expression of any opinion whatsoever on the part of Research Square concerning the legal status of any country, territory, city or area or of its authorities, or concerning the delimitation of its frontiers or boundaries. This map has been provided by the authors. 